\title{
METROSEXUAL IDENTITY: PERCEPTION OF MALAYSIAN MALE CONSUMERS TOWARDS COSMETIC AND SKINCARE PRODUCT
}

\author{
Wee Ming Lau \\ Business Development Department, Wawasan Open University, \\ Kuching Branch, Malaysia \\ Ernest Cyril de Run \\ Faculty of Economics and Business, Universiti Malaysia Sarawak, \\ Kota Samarahan, Malaysia \\ Teck Weng Jee \\ Faculty of Business and Design, Swinburne University of Technology, \\ Kuching, Malaysia
}

*Corresponding author:

Email Address: wmlau@wou.edu.my

\begin{abstract}
The main purpose of this study is to explore the perceptions of cosmetics and skin care products in Malaysian metrosexual men. The scope of this study is limited to Malaysian males aged between 20 50 years old. A total of 105 respondents were interviewed and only 100 complete interviews was used. The results show that majority of respondents believed that cosmetics are for ladies while skin care products are associated with protection. Respondents also stated that men who use cosmetics and skin care products in daily life are normal. This study suggests that the relationship between consumer trends and social acceptance demonstrates the influence of new consumer culture. Moreover, the new consumer culture brings the opportunity to the cosmetics industry which has been saturated by female consumers.
\end{abstract}

Keywords: Metrosexual, Perception, Cosmetic and Skin Care

\section{INTRODUCTION}

Research on cosmetics and skin care products have traditionally focused on women as the predominant consumer (Cash, Dawson, Davis, Bowen, \& Galumbeck, 2001).Of late, a new niche market has emerged with the increased demand of skin care products for men who are more aesthetically conscious and are known as metrosexuals. The term metrosexual refers to an urban male 
of any sexual orientation who has strong aesthetic sense and spends a lot of time as well as money on his appearance and lifestyle (Miller, 2005).

It is a growing trend in Malaysia for men to put an effort by adopting a regular skincare regime as means to pamper themselves by investing in a variety of grooming products. It is evident in the bourgeoning of spa centres, skin care treatments, products and magazines specifically targeting men who are eager to maintain a presentable image through the means of willingness to spend time, energy and money to look good(Matthews, 1996). This trend started when English soccer player David Beckham, confessed that he is obsessed with skin care treatments, cosmetics, as well as pursuing latest fashion (Simpson, 2002). Subsequently, a study by Featherstone (1993) purported that there have been a significant increase in the numbers of men who are dedicated in projecting a positive body image and appearance by favouring beauty institutions that provides products and services in dietary, slimming, exercise and cosmetics.

Prior to the evolutionary rise of the metrosexual male phenomenon, most men were not inclined to dabble in cosmetics and skin care products. Generally, most men would feel intimidated when visiting the cosmetics section at a department store (Daniels, 2005). Now with the existence of metrosexual icon such as David Beckham, many men are willing to approach these counters without hesitance and purchase these products. Hence, this research will further investigate their behaviour. The perception of metrosexual is studied as well in order to know the acceptance level of metrosexual men by traditional men who turn down cosmetics and skin care products.

\section{LITERATURE REVIEW}

People generally perceive men from various characteristics that distinguish man from woman such as genetically, sexually and gender related behaviours(Chesebro \& Fuse, 2001). Men's primary sexual characteristics are reproductive systems such as penis, testicles, vas deferens, sperm chords and prostate glands (Strachan, 1992).Secondary sexual characteristics are mainly physical characteristics such as body hair, muscle growth, larger jawbones, more prominent cheekbones, thinner cheeks, deep tone voice and so forth (Chesebro \& Fuse, 2001).

Men generally behave differently compared to women. For instance, men are known to be more aggressive, courageous, self -confident, less emotional and competitive when compared to (Chesebro \& Fuse, 2001). Furthermore, men possess better technical and organizational skill than women. In today's society, there are various perceptions towards the term "metrosexual". Previous scholarly works have conceptualised metrosexual male as a person who is fashionably sensitive, self obsessed and keen to pamper and indulge themselves in grooming products (Donna, 2004;Brune, 2004). Similarly, a metrosexual male is depicted as someone who is a dandyish narcissist in love with not only himself, but with his urban lifestyle as well as a straight man who is in touch with his feminine side (John, 2003).Furthermore, others perceive metrosexual as an urban male with a high disposal income and willing to spend a great deal of time of his appearance and lifestyle (Donoghue, 2005). With the emergence of the "new man, the traditional image of men ascribed as masculine, rough, dirty and unshaven has changed to describe men who engage in their feminine side and care more about their appearances (Haluk Koksal, 2014).

The use of cosmetics and skin care products by males has become a common practice in society. Many male celebrities have confessed that they are ardent fans of both cosmetics and skin care products as it makes them feel more comfortable after using these products, hence it has become a regular routine in their life. When examining the consumption of cosmetics and skin care products, there is copious academic research identifying women to be more likely to shop for aesthetic products, while men are more likely to shop for functional products (Dittmar et al., 1996; Rook and Hoch, 1985).Moreover, cosmetics, skin care, spas, beauty tips, latest fashion, healthy diets and so 
forth have been associated with females' traits. With today's new breed of men, it has caused a blur in the gender line.As such, this reflects a much broader shifts socially and culturally leading towards a more multifarious and less rigid way of stereotyping gender differences. The new age men possess refined aesthetic sense which is commonly link to homosexual (Jorge, 2004). Scholars have also paid attention to the distinctiveness between homosexual and metrosexual traits, highlighting that both are interested in art, fashion, image conscious, romantic and sensitive (Simpson,2002;Berman,2004).It is interesting to note that such similarities does not extend beyond sexual orientation as homosexual men are known to be attracted to same gender whereas metrosexual men are described as those who have good sense in fashion(John, 2003).

Men have been using cosmetics and skin care products even before the metrosexual term is coined. It has been accorded that 10 to 15 percent of some skin care products intended for women are already personally being used by men (Berman, 2004). The influential role of media have further epitomised the term "metrosexual" especially with Mark Simpson's article titled "Meet the Metrosexual" by further framing the changes in how masculinity is constructed in Western society. Given the media's strong influential nature towards people's perceptions, the aforementioned article have popularised the metrosexual culture through celebrity soccer star David Beckham (Merritt, 2004). The famous English captain is listed as one of the top players in world soccer league and also well-known for his portrayal as someone who embraces the values of a metrosexual male (Jorge, 2004).In a similar vein, magazines such as GQ, FHM, The Face, Maxim, Men's Health, Cargo and so forth had emasculated the phenomenon by displaying good looking male models gracing the front cover of the magazines(Simpson, 2002). Subsequently, television shows such as Queer Eye for the Straight Guys and Man Hunt: The Search for the America Most Gorgeous Male Model have reaffirmed the stereotype of metrosexual domain(Jorge, 2004).

The metrosexual male's consumption of cosmetic and skin care products are not primarily associated with creating a favourable self-image and identities, but also for self-satisfaction. This has led to the Yet, the developments of cultural studies, feminism, poststructuralist, globalisation processes and queer theory are urging the concept of self and identity (Callero, 2003).

The word cosmetic originally comes from Rome 'cosmetae', which means slave in charge for the decoration of mistress(Mahoney, 2009). Initial definition for cosmetic (make-up) is referred as changing a person's body or facial look using paints, powders, unguents, emulsions, and enamels applied to the skin (Anonymous, 2004). The cosmetics are used to improve one's look in order to make him look younger (Anonymous, 2004; John, 2003).

Skin care is defined as care for skin through the consumption of certain products either internally or externally. The consumption of skin care started as early as 10,000 BC whereby men would use fragrant oils and ointment to clean and mask body odour (Anonymous, 2003). Moreover, men are now motivated to use skin care products to protect their skin from skin damage due to daily pollution and the harsh environment (Matthews, 1996).

Symbols and communication strategies are used in the self-construction. The resources of self-construction are diverse and include storytelling, cultural narratives, political ideologies, roles, identities, corporal body and products (Callero, 2003). Products as self-construction will be mainly discussed for metrosexual issue. Thus, an important component of the self-concept is body image. People tend to perceive themselves how others judge them(Hanna \& Wozniak, 2001). There is a vivid increase in individuality and self-expression through various ways such as use of clothes, hair style, body decoration and body movement among young men (Sturrock \& Pioch, 1998).

Problems arise when men feel that their image should differ from their real image hence resulting in the use of skin care and cosmetic products as the solution. Marketer should grab this opportunity to manipulate the "metrosexual" term to enlarge their market. Behavioural Learning Theory assumes that learning takes place as the result of response to external events (Solomon, 2004). 
Information Processing Perspective of Consumer Behaviour is the logical flow model to explain consumer behaviour ( Holbrook \& E.C Hirschman, 1982). See Figure 1.

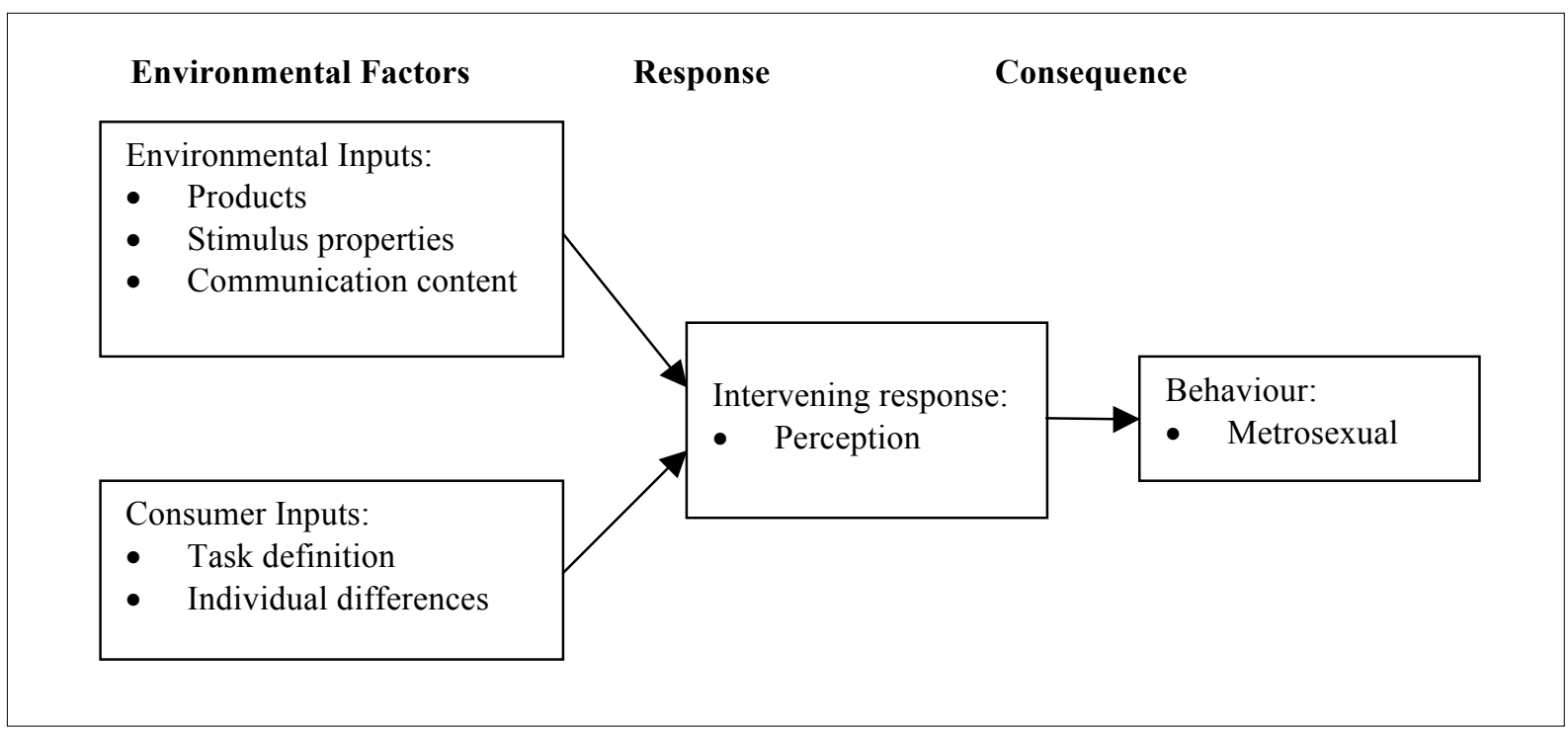

Figure 1. Information Processing Perspective of Consumer Behaviour (Holbrook \& Hirschman,1982)

\section{RESEARCH METHODOLOGY}

This study used exploratory research that intends to provide insights and understandings ofa particular incident. Exploratory research is an initial research conducted to clarify and define nature of a problem (Zikmund, 2003).It provides information to use in analyzing a situation but not to reveal conclusive evidence to determine certain course of action (Zikmund, 2003). Subsequent research is expected to provide conclusive research. This study employs exploratory research in order to gain initial understanding of metrosexual using cosmetics and skin care.

This study only comprises of Malaysian males. The population in this study were thoseof 20 years old and above. This age range is selected as they are considered as professional, mature thinking and have time and money to invest to create self image via lifestyle they are experiencing (Sturrock \& Pioch, 1998). The respondents were selected on a non-probability sampling basis. The respondents were selected through convenience sampling. Convenience sampling is non-probability technique that attempt to obtain a sample of convenient elements (Malhotra, 2004). The interview took 105 male respondents to gain insights and idea of the issue in exploratory research. As rule of thumb, 25 interviews per country is acceptable with condition respondents are potential while 30 interviews are common (Clifton, Nguyen, \& Nutt, 1992).

Primary data was collected from selective convenience sampling of 105 male respondents in Malaysia. The primary data collected was the data about perception of men toward cosmetics and skin care products and view of men who use cosmetics and skin care. Data collected was employed in order to address the specific objective.

\section{FINDINGS}

After eliminating the spoilt interview records and incomplete interview only 100 of complete interviews were able to use. All respondents were male, aged $20-50$ years old and possess an amount of disposable income. The respondents' demographics that include their gender, age, occupation and income were determined and shown in Table 1. 
Table 1

Respondents' Demographics

\begin{tabular}{llcc}
\hline Demographics & Frequency & $\begin{array}{c}\text { Percentage } \\
(\%)\end{array}$ \\
\hline Gender & Male & 100.0 & 100.0 \\
Age & Female & 0.0 & 0.0 \\
& 20 & 13.0 & 13.0 \\
& $21-25$ & 77.0 & 77.0 \\
Occupation & $26-30$ & 8.0 & 8.0 \\
& $45-50$ & 2.0 & 2.0 \\
Income & Student & 64.0 & 64.0 \\
(RM) & Blue collar & 11.0 & 11.0 \\
& White collar & 25.0 & 25.0 \\
& $<1000$ & 69.0 & 69.0 \\
& $1001-2000$ & 23.0 & 23.0 \\
& $2001-3000$ & 4.0 & 4.0 \\
& $4001-5000$ & 3.0 & 3.0 \\
& $>5000$ & 1.0 & 1.0 \\
\hline
\end{tabular}


Table 2 indicates the findings for perceptions towards cosmetic products.

Table 2

Perceptions towards Cosmetic Products

\begin{tabular}{|c|c|c|c|c|c|c|c|c|}
\hline \multirow{2}{*}{$\begin{array}{l}\text { Perception of Men Toward } \\
\text { Cosmetics }\end{array}$} & \multirow[b]{2}{*}{$\begin{array}{c}\text { Overall } \\
\%\end{array}$} & \multicolumn{2}{|c|}{ Age } & \multicolumn{2}{|c|}{ Income (RM) } & \multicolumn{3}{|c|}{ Professionalism } \\
\hline & & $\begin{array}{c}20-25 \\
\%\end{array}$ & $\begin{array}{c}26-50 \\
\%\end{array}$ & $\begin{array}{c}<1000- \\
2000 \\
\%\end{array}$ & $\begin{array}{c}2001- \\
>5000 \\
\%\end{array}$ & $\begin{array}{l}\text { Student } \\
\%\end{array}$ & $\begin{array}{c}\text { Blue } \\
\text { collar } \\
\%\end{array}$ & $\begin{array}{c}\text { White } \\
\text { collar } \\
\%\end{array}$ \\
\hline For Ladies & 22.0 & 100.0 & 0.0 & 86.4 & 13.6 & 72.7 & 9.1 & 18.2 \\
\hline Beauty & 21.0 & 95.2 & 4.8 & 90.5 & 4.7 & 52.4 & 4.8 & 42.9 \\
\hline Look & 12.0 & 91.6 & 8.3 & 83.4 & 16.6 & 58.3 & 8.3 & 33.3 \\
\hline No Comment & 11.0 & 90.9 & 9.1 & 100.0 & 0.0 & 45.5 & 18.2 & 36.4 \\
\hline Good & 9.0 & 55.5 & 44.4 & 100.0 & 0.0 & 77.8 & 22.2 & 0.0 \\
\hline Waste of Money & 6.0 & 100.0 & 0.0 & 100.0 & 0.0 & 66.7 & 0.0 & 33.3 \\
\hline Confidence & 5.0 & 80.0 & 20.0 & 80.0 & 20.0 & 80.0 & 0.0 & 20.0 \\
\hline No need & 4.0 & 100.0 & 0.0 & 100.0 & 0.0 & 75.0 & 0.0 & 25.0 \\
\hline Protection & 4.0 & 75.0 & 25.0 & 100.0 & 0.0 & 75.0 & 25.0 & 0.0 \\
\hline Expensive & 4.0 & 75.0 & 25.0 & 100.0 & 0.0 & 50.0 & 25.0 & 25.0 \\
\hline Make Up & 3.0 & 100.0 & 0.0 & 100.0 & 0.0 & 100.0 & 0.0 & 0.0 \\
\hline Unisex & 3.0 & 66.7 & 33.3 & 66.7 & 33.3 & 33.3 & 33.3 & 33.3 \\
\hline Occasionally Used & 3.0 & 66.7 & 33.3 & 100.0 & 0.0 & 100.0 & 0.0 & 0.0 \\
\hline Clean & 3.0 & 66.6 & 33.3 & 100.0 & 0.0 & 66.7 & 0.0 & 33.3 \\
\hline Improvement & 3.0 & 100.0 & 0.0 & 100.0 & 0.0 & 66.7 & 0.0 & 33.3 \\
\hline Not Suitable for Men & 2.0 & 100.0 & 0.0 & 100.0 & 0.0 & 100.0 & 0.0 & 0.0 \\
\hline Healthy & 2.0 & 100.0 & 0.0 & 100.0 & 0.0 & 100.0 & 0.0 & 0.0 \\
\hline Useful & 1.0 & 100.0 & 0.0 & 100.0 & 0.0 & 100.0 & 0.0 & 0.0 \\
\hline Value Added & 1.0 & 100.0 & 0.0 & 100.0 & 0.0 & 100.0 & 0.0 & 0.0 \\
\hline Not Interested & 1.0 & 100.0 & 0.0 & 100.0 & 0.0 & 100.0 & 0.0 & 0.0 \\
\hline For Male Staffs & 1.0 & 0.0 & 100.0 & 100.0 & 0.0 & 0.0 & 0.0 & 100.0 \\
\hline Not Like it & 1.0 & 100.0 & 0.0 & 100.0 & 0.0 & 100.0 & 0.0 & 0.0 \\
\hline Maintain their Skin & 1.0 & 100.0 & 0.0 & 100.0 & 0.0 & 0.0 & 0.0 & 100.0 \\
\hline Women & 1.0 & 100.0 & 0.0 & 0.0 & 100.0 & 0.0 & 0.0 & 100.0 \\
\hline Not Natural & 1.0 & 100.0 & 0.0 & 100.0 & 0.0 & 100.0 & 0.0 & 0.0 \\
\hline Many Brands & 1.0 & 100.0 & 0.0 & 100.0 & 0.0 & 100.0 & 0.0 & 0.0 \\
\hline Doubt Ingredients & 1.0 & 0.0 & 100.0 & 0.0 & 100.0 & 0.0 & 0.0 & 100.0 \\
\hline Doubt Safety & 1.0 & 0.0 & 100.0 & 0.0 & 100.0 & 0.0 & 0.0 & 100.0 \\
\hline Interesting & 1.0 & 100.0 & 0.0 & 100.0 & 0.0 & 100.0 & 0.0 & 0.0 \\
\hline For All Ages & 1.0 & 0.0 & 100.0 & 100.0 & 0.0 & 0.0 & 100.0 & 0.0 \\
\hline Men Seldom Use & 1.0 & 100.0 & 0.0 & 100.0 & 0.0 & 0.0 & 100.0 & 0.0 \\
\hline Extra Substance & 1.0 & 100.0 & 0.0 & 100.0 & 0.0 & 100.0 & 0.0 & 0.0 \\
\hline
\end{tabular}


Table 3 indicates the findings for perceptions towards skin care products.

Table 3

Perceptions toward Skin Care Products

\begin{tabular}{|c|c|c|c|c|c|c|c|c|}
\hline \multirow[b]{2}{*}{$\begin{array}{l}\text { Perception Toward Skin } \\
\text { Care Products }\end{array}$} & \multirow[b]{2}{*}{$\begin{array}{c}\text { Overall } \\
\%\end{array}$} & \multicolumn{2}{|c|}{ Age } & \multicolumn{2}{|c|}{ Income (RM) } & \multicolumn{3}{|c|}{ Professionalism } \\
\hline & & $\begin{array}{l}20-25 \\
\%\end{array}$ & $\begin{array}{l}26-50 \\
\%\end{array}$ & $\begin{array}{c}<1000 \\
-2000 \\
\%\end{array}$ & $\begin{array}{c}2001 \\
-> \\
5000 \\
\%\end{array}$ & $\begin{array}{c}\text { Student } \\
\%\end{array}$ & $\begin{array}{c}\text { Blue } \\
\text { collar } \\
\%\end{array}$ & $\begin{array}{c}\text { White } \\
\text { collar } \\
\%\end{array}$ \\
\hline Protection & 17.0 & 82.4 & 17.6 & 100.0 & 0.0 & 47.0 & 6.0 & 47.0 \\
\hline Healthy & 13.0 & 92.3 & 7.7 & 92.3 & 7.7 & 53.8 & 15.4 & 30.8 \\
\hline Care Men and Women & 11.0 & 92.9 & 9.1 & 90.9 & 9.1 & 90.9 & 9.1 & 0.0 \\
\hline Self Purity & 10.0 & 80.0 & 20.0 & 90.0 & 10.0 & 40.0 & 20.0 & 40.0 \\
\hline Look & 9.0 & 88.9 & 11.1 & 100.0 & 0.0 & 77.8 & 11.1 & 11.1 \\
\hline No Comment & 8.0 & 87.5 & 12.5 & 87.5 & 12.5 & 25.0 & 37.5 & 37.5 \\
\hline Perfect & 8.0 & 87.5 & 12.5 & 87.5 & 12.5 & 87.5 & 12.5 & 0.0 \\
\hline Care for Skin & 8.0 & 88.9 & 11.1 & 100.0 & 0.0 & 77.8 & 0.0 & 22.2 \\
\hline Good & 7.0 & 71.4 & 28.6 & 85.8 & 14.2 & 42.9 & 14.2 & 42.9 \\
\hline Useful & 5.0 & 100.0 & 0.0 & 100.0 & 0.0 & 80.0 & 20.0 & 0.0 \\
\hline Useless & 3.0 & 100.0 & 0.0 & 100.0 & 0.0 & 100.0 & 0.0 & 0.0 \\
\hline Occasionally Used & 3.0 & 100.0 & 0.0 & 100.0 & 0.0 & 100.0 & 0.0 & 0.0 \\
\hline Corrector & 3.0 & 100.0 & 0.0 & 66.7 & 33.3 & 33.3 & 33.3 & 33.3 \\
\hline For Ladies & 3.0 & 33.3 & 0.0 & 66.7 & 33.3 & 66.7 & 0.0 & 33.3 \\
\hline Common & 2.0 & 100.0 & 0.0 & 100.0 & 0.0 & 100.0 & 0.0 & 0.0 \\
\hline Not Necessary for Men & 2.0 & 100.0 & 0.0 & 100.0 & 0.0 & 100.0 & 0.0 & 0.0 \\
\hline Beauty & 2.0 & 100.0 & 0.0 & 100.0 & 0.0 & 100.0 & 0.0 & 0.0 \\
\hline Expensive & 2.0 & 100.0 & 0.0 & 100.0 & 0.0 & 50.0 & 0.0 & 50.0 \\
\hline Essential & 2.0 & 50.0 & 50.0 & 100.0 & 0.0 & 50.0 & 50.0 & 0.0 \\
\hline Smelly & 1.0 & 100.0 & 0.0 & 100.0 & 0.0 & 100.0 & 0.0 & 0.0 \\
\hline More Skin Care Products & 1.0 & 0.0 & 100.0 & 0.0 & 100.0 & 0.0 & 0.0 & 100.0 \\
\hline Prevention & 1.0 & 100.0 & 0.0 & 100.0 & 0.0 & 100.0 & 0.0 & 0.0 \\
\hline Waste of Money & 1.0 & 100.0 & 0.0 & 0.0 & 100.0 & 0.0 & 0.0 & 100.0 \\
\hline Substitute & 1.0 & 100.0 & 0.0 & 100.0 & 0.0 & 100.0 & 0.0 & 0.0 \\
\hline White & 1.0 & 100.0 & 0.0 & 100.0 & 0.0 & 100.0 & 0.0 & 0.0 \\
\hline Doubt Ingredients & 1.0 & 0.0 & 100.0 & 0.0 & 100.0 & 0.0 & 0.0 & 100.0 \\
\hline Must Safe to Human & 1.0 & 0.0 & 100.0 & 0.0 & 100.0 & 0.0 & 0.0 & 100.0 \\
\hline Fantastic & 1.0 & 100.0 & 0.0 & 100.0 & 0.0 & 100.0 & 0.0 & 0.0 \\
\hline Not every Product is Perfect & 1.0 & 100.0 & 0.0 & 100.0 & 100.0 & 0.0 & 0.0 & 0.0 \\
\hline Daily Used & 1.0 & 100.0 & 0.0 & 0.0 & 100.0 & 100.0 & 0.0 & 0.0 \\
\hline
\end{tabular}

\section{DISCUSSION}

The issue of understanding the different perception toward cosmetics and skin care products among Malaysian metrosexual men is of great importance. More men in Malaysia which consider themselves as metrosexual is adopting and investing in cosmetics and skin care products over the last decades(Cheng, Ooi, \& Ting, 2010). In contrast, with previous studies claiming aesthetics and fashion are significantly more feminine oriented (Ricciardell \& Clow, 2013), suggesting a different understanding of masculinity traits. The view of gender had traditionally viewed men as aggressive, courageous, adventurous and competitive behaviour(Chesebro \& Fuse, 2001), and are more selfconfident and self-controlled than the opposite gender(Chesebro \& Fuse, 2001). This can be seen from the perception they have on both cosmetics and skin care products. The findings in Table 2 indicated that majority of men which consider themselves as metrosexual however still perceived cosmetic products are generally for ladies, beauty, to increase their overall look and impression. On the other hand, the findings in Table 3 shows that men which consider themselves as metrosexual 
would perceived cosmetic products generally as a form of protection, health related, and to increase their overall look.

Clearly, how Malaysian metrosexual male's perception towards cosmetics and skin care products warrants better insights. Targeted stimuli or factors such as cosmetic products are for ladies and for beatification purposes, and skin care products is for protection and health related will only be effective when the target sample is of significant to the overall population. This is particularly evident in Malaysia as feminism had become an integral part of the overall societal build-up (Ariffin, 1999). Such feminism within a masculine dominant society such as Malaysia also uphold values such as competition, achievement and success values (Hofstede, 2001). However, the findings seem to be hardly generalizable as metrosexual men are still at its infancy stage in Malaysia (Cheng et al., 2010). This leads to the need for more replication of the same study on the opposite gender, sexual orientation, and different ethnicities in Malaysia.

\section{CONCLUSION}

This study is aimed to determine male consumers' perception in Malaysia toward skin care and cosmetics. Respondents assumed that cosmetics are for women and only used by them while skin care products are suitable for both sexes. Cosmetics and beauty are both entwined as the former is used to beautify one person or to achieve a desired image. Most of the respondents' perception toward metro sexuality is normal, although minority doubted their sexual orientation, treated themselves different, and believed that metrosexual is exclusive to them. The findings indicated that men tend to emphasis more on skin care products than cosmetic products. As such; companies are able to draw more specific marketing campaigns to target such metrosexual male consumers. This research will then be able to provide greater insight for marketers and practitioners alike with sound strategies and insights when it comes to targeting metrosexual men.

\section{Limitation and Future Research}

The sampling method carried out in this study was based on convenience sampling method. Such methods generally create a condition where it limits the generalizability of the findings, especially when the population of study consist of other demographic segments such as different ethnicities and religions. At the same time, the replication of such study from female to metrosexual male is still not a popular topic among consumer behaviour/ marketing/ and advertising literature, and yet as the findings here indicate, there is a need to do so.

Future research can be done on female perception on male using cosmetic and skin care product. It will be an interesting gender research on female views of male using cosmetic and skin care product. A comparative research can also be conducted to determine different ethnicities perception towards cosmetics and skin care products.

\section{ACKNOWLEDGEMENT}

This paper is dedicated to my mentor, friend and former supervisor the late Prof Dr. Ernest Cyril de Run. His enthusiasm and commitment in nurturing novice researchers have been relentless. 


\section{REFERENCE}

Anonymous. (2003). A History of Men's Grooming: Men's Makeup and Skin Care. Retrieved 20 August, 2005, from http://www.4voo.com/education/ed history.htm

Anonymous. (2004). Making-up is Hard to Do. Retrieved 30 August, 2005, from http://www.users.bigpond.com/sacasmo/sexpolitics/makeup.html

Berman, L. A. (2004). Who Are the Metrosexuals? . Retrieved 15 October, 2005, from http://www.narth.com/docs/metrosexuals.html

Brune, E. 2004. "Metrosexual', License", vol. 7, no. 7, pp. 14-15

Callero, P. L. (2003). The Sociology of the Self. Annual Review of Sociology. Palo Alto: 2003, 29, 115.

Cash, T. F., Dawson, K., Davis, P., Bowen, M., \& Galumbeck, C. (2001). Effects of Cosmetics Use on the Physical Attractiveness and Body Image of American College Women. The Journal of Social Psychology, 129(3), 349-355.

Cheng, F. S., Ooi, C. S., \& Ting, D. H. (2010). Factors affecting consumption behavior of metrosexual toward male grooming products. International Review of Business Research Papers, 6(1), 574-590.

Chesebro, J. W., \& Fuse, K. (2001). The Development of a Perceived Masculinity Traits. Communication Quarterly, 49, 203-279.

Chrisafis, A. (2003). Neutered Modern Man to be Offered Back His Missing Pride in Exchange for His Wallet. Retrieved 30 August, 2005, from http://www.guardian.co.uk/uk news/story/0,3604,978193,00.htm

Clifton, P., Nguyen, H., \& Nutt, S. (1992). Market Research: Using Forecasting in Business. Oxford: Butterworth-Heinemann.

Daniels, C. (2005). Fear Factor. Retrieved 2005, from http://www.marketingmag.ca/magazine/current/feature/article.jsp?content=20050207 66489 66489

Donoghue, L. 2005. 'Men Choose Science or Simplicity?', Global Cosmetic Industry”, vol. 173, no. 9, pp. 30-32.

Donna, C. B. 2004. "From grudginator to experimenter', Global cosmetic industry", vol. 172, no. 3, pp. 21-21

Featherstone, M. (1993). The Body-Social Process and Cultural Theory. London: Sage Publication. Hanna, N., \& Wozniak, R. (2001). Consumer Behaviour: An Applied Approach. NJ: Prentice Hall.

Hofstede, G. (2001). Culture's consequences: Comparing values, behaviors, institutions and organizations across nations. Thousand Oaks, CA: Sage.

Holbrook, M. B., \& Hirschman, E. C. (1982). The Experiential Aspects of Consumption: Consumer Fantasies, Feelings, and Fun. Journal of Consumer Research, 9(2), 132.

Janowska, K. (2008). Metrosexual men's shopping habits: study of the modern men's clothing brand selection.

John, S. (2003). The Metrosexual Man. Retrieved 30 August 2005, from http://www.theweek.com/23nov16/cover.htm

Jorge, R. (2004). The Evolution of New Men. Retrieved 15 October, 2005, from http://www.manilatimes.net/national/2004/feb/20/yehey/life/20040220lif3.html

Mahoney, K. D. (2009). LATdict - An Online Latin Dictionary. Retrieved 25 March, 2009, from http://www.latin-dictionary.net/info/word/14514.html

Malhotra, N. K. (2004). Marketing Research: An Applied Orientation. London: Prentice Hall International.

Matthews, I. (1996). Man Alive. Soap, Perfumery \& Cosmetics, 69(12), 19.

Merritt, A. (2004). It's About Time You Meet the Metrosexual. Retrieved 15 October, 2005, from http://www.queensjournal.ca/article.php?point=vol131/issue17/postscript/lead1

Miller, T. (2005). A Metrosexual Eye on Queer Guy. A Journal of Lesbian and Gay Studies 11(1), 112-117.

Ricciardelli, R., \&Clow, K. A. (2013). The portrayal of elements historically associated with masculine and feminine domains in lad and metrosexual men's lifestyle magazines. Masculinities \& Social Change, 2(2), 116-145. 
Seah, L. (2003). More than Macho, Being Metrosexual is the In Thing Now. Retrieved 15 October, 2005, from http://xiaogou.org/extra/metrosexual.html

Simpson, M. (2002). Meet the Metrosexual. Retrieved 20 August, 2005, from http://www.salon.com/ent/feature/2002/07/22/metrosexual.index.htm

Solomon, M. R. (2004). Consumer Behavior: Buying, Having and Being. Upper Daddle River, New Jersey: Pearson Education.

Strachan, T. (1992). The Human Genome. Oxford: BIO Scientific Publishers Limited.

Sturrock, F., \& Pioch, E. (1998). Making Himself Attractive: The Growing Consumption of Grooming Products. Marketing Intelligence and Planning, 16(5), 337-343.

Zikmund, W. G. (2003). Business Research Method. Ohio: South-Western. 